degree. His first academic appointment was as assistant lecturer in organic chemistry at Manchester in 1930, under the late Prof. Lapworth. With the appointment of I. M. Heilbron to Manchester on the retirement of Lapworth, the Heilbron and Spring collaboration was resumed, and many papers, particularly on the chemistry of ergosterol, vitamin D and related compounds, testified to the success of the collaboration. With the departure of Heilbron to the Imperial College, London, Spring continued his interest in the chemistry of natural products, going on to studies in the triterpene group and especially the constitution of the $\alpha$ - and $\beta$-amyrins. He was awarded the D.Sc. (Manchester) in 1937, and made a senior lecturer in 1941. More recently, with an active research team, he has broken new ground in studies on the application of the Hofmann reaction to the synthesis of heterocyclic compounds, and in addition has carried out investigations for the Colonial Products Research Council.

At Manchester, Dr. Spring proved himself a very successful teacher and an able lecturer, his interest in the chemistry of natural products adding enthusiasm to his lectures to medical students and others. He has always been a staunch supporter of the Chemical Society, being at present a member of its Council, and, as well as being a frequent contributor of original papers, he has taken a very active part in the compilation of the annual reports published by the Society. During the War, Dr. Spring has acted as senior gas adviser to the North-West Regional Commissioner, and was responsible for the training of gas identification officers in this area, and, in association with Prof. A. R. Todd, carried out research for the Ministry of Supply.

\section{Statistics in the Modern State}

In his presidential address to the Royal Statistical Society on November 22, Lord Woolton said that the progress in statistics in public affairs in Great Britain during the last half-century has enabled the reading public to form political opinions and provided precise information for Ministers of the Crown, business men and the trade union movement. By 1939 the supply of information was comprehensive enough to show the size of the resources of the country and how they were being used; but there were many gaps in the information available, and those who found themselves in 1939 resporsible for the government of the country in the rapidly changing conditions of the War had very little to help them. The proved competence of the statistician, both in the field of financial forecast and in the operations of Government, have given much stimulus to those who believe in national planning, and in particular, to its use in preventing economic waste and personal tragedy. Unemployment is the most urgent social problem confronting the modern State, and Lord Woolton believes that the use of the statistical method of ordering those operations of our economic life that are within the control and competence of Government can in a large measure solve the problem. We must have knowledge of facts, and capacity to forecast future trends from those facts ; but it is useless and aggravating to call for information in greater detail than is necessary to provide proper guidance to action. Enumerating the principal classes of statistics that must be obtained for the efficient operation of an employment policy, Lord Woolton said that to collect the information involves maintaining close collaboration between statisticians in Government services and their professional colleagues in trade associations, in the universities and research institutes.

\section{Committee on Scientific Man-power and Resources}

Mr. H. Morrison, Lord President of the Couneil, announced in the House of Commons on November 29 that he has appointed a Committee "to consider the policies which should govern the use and development of our scientific man-power and resources in the next ten years". The Committee is being asked to produce an early interim report to facilitate forward planning in fields which are dependent on the use of scientifie man-power. Later the Committee will be asked to make recommendations for the establishment of permanent machinery for carrying out surveys into the best use of the scientific resources of Britain in the national interest. The Committee is constituted as follows: Sir Alan Barlow (temporary chairman), Sir Edward Appleton, Prof. P. M. S. Blackett, Mr. Geoffrey Crowther, Sir Alfred Egerton and Sir George Nelson.

\section{Engineers' Study Group on Economics}

Sir Richard Paget, retiring president of the Engineers' Study Group on Economics, at the annual general meeting held on December 1, announced that Sir John Boyd Orr will be president for the coming year, with Sir Geoffrey Bracken (formerly finance minister to the Madras Presidency) as deputy president. Sir Richard outlined some tasks that the Group might undertake. There is still an urgent need for the clarifying of public opinion throughout the world on the true role of money and as to the principles by which all nations should be guided in providing their national currencies and exchanging their surplus products for the common good of the world at large. Gold-a valuable metal-which could be profitably employed in making glorious and everlasting works of art for the admiration and delight of posterity, still lies buried in vaults. The problem of 'the role of money' might be made the subject of an impartial investigation by a team of economists and financial experts from many countries, similar to the teams of workers who, during the War, successfully attacked many scientific problems.

Sir Richard Paget further stated that the Ethies Section of the Engineers' Study Group, together with the Religious and Scientific Research Group, are paying special attention to developing an international ethical system, a code to which men and women of all nationalities, and all creeds, could agree. A stable world will need stable ethical foundations, fearlessly built on the rock of ascertainable truthon fact rather than on faith.

\section{Shirley Fellowship Awards}

The British Cotton Industry Research Association has awarded the first two Shirley Fellowships for postgraduate research to $\mathrm{Mr}$. F. Brown and Mr. T. G. Halsall, both of the University of Manchester, who will work on carbohydrate chemistry under the direction of Prof. E. L. Hirst. Mr. Brown has been working on chromatographic and other methods for the separation of closely related carbohydrate derivatives, and Mr. Halsall has been studying the action of periodate ions on polysaccharides. The new methods of end-group determination thus developed will be applied to problems in the chemistry of starch and cellulose. The fellowships date from January 1, 1946. 